\title{
Editorial
}

(The following editorial is adapted from a speech given on May 3, 1996, at the first annual meeting of the Molecular Medicine Society.)

\section{SCIENCE AND MEDICINE-1996}

\author{
Floyd E. Bloom, M.D., Editor-in-Chief, Science, Councillor, \\ Molecular Medicine Society, Chairman, \\ Department of Neuropharmacology, Scripps Research Institute
}

When I decided to title my talk "Science and Medicine," I had two relationships in mind: the one between science, with small letters, and medicine and the one between Science, the magazine, and medicine, the field. The latter relationship is one inherent to this classic weekend, the first weekend in May, when the historical clinical tri-societies meet. ${ }^{1}$ These are the societies that David Nathan and Carl Moore instilled in us the desire to participate in, where our achievements would be recognized and we would grow from the Young Turks ${ }^{2}$ to the Old Turks, ${ }^{3}$ the highest form of acclaim one could have in those days. When the chance arose to give a talk here, from the perspective of my position at Science magazine, I was very pleased at least to ruminate over both of these relationships. Thinking about science and medicine while in Washington, DC, makes one recognize that the world that we all live in, the world of scientific and medical research, is embedded in a very bizarre political climate which is frustrating us all. The current climate makes it very difficult for us to see far ahead into the future, where we were never afraid to look before. I would like to end my talk with some thoughts on this issue.

How did I get to this point, of being able to talk to you here about Science, the magazine, and

\footnotetext{
${ }^{1}$ The clinical research meeting held May 3-6, 1996 in Washington, D.C., was organized by the Association of American Physicians (AAP), the American Society for Clinical Investigation (ASCI), and the American Federation for Clinical Research (AFCR).

${ }^{2}$ Members of the ASCI.

${ }^{3}$ Members of the AAP.
}

medicine? I think, if I can remember the trail correctly, that it began when Ajit Varki, who is the editor of the Journal of Clinical Investigation, came to talk to me about a particular problem of human medical biology that interested him and that he wanted me to reflect on. During the course of that conversation, it came up-and he was amazed to find-that not only was I an M.D. but I had also been in internal medicine and a member of the American Society of Clinical Investigation (I had had to drop out when my neuroscience research absorbed all my time). It was not long after that conversation that I received a telephone call from Rick Klausner, ${ }^{4}$ who wanted me to come down to San Diego for the weekend to meet with the clinical tri-societies. $\mathrm{He}$, along with Judith Swain, ${ }^{5}$ then invited Science to become a co-host of the meeting in 1996 and try to provide the meeting with coherence and, perhaps, publicity on a larger scale than had been done before. I was really pleased when Science did become part of the program committee and participated in "Biomedicine '96" in a small way.

At the same time, Ken Warren had been in communication with me (as he had been with Dan Koshland before Dan left the job of editorin-chief of Science) about the possibility that what is now the Molecular Medicine Society work with Science to hold a meeting that would carry on in the tradition of their human genome project meetings, which had been dropped three or four years ago. We were never quite able to

\footnotetext{
${ }^{4}$ Past President of ASCI and, currently, Director of NCI.

${ }^{5}$ President of ASCI.
} 
bring that off, and, when it looked like we were getting close, the opportunity to work with the clinical tri-societies came up. In the end, I was very pleased when the program committee for the councils of those societies agreed that the Molecular Medicine Society could meet in conjunction with the three. Now, in the tradition of those continually evolving medical societies, with the Old Turks spawning the Young Turks spawning the American Federation for Clinical Research, we have the Molecular Medicine Society, which might serve as the intellectual leveler, where one can talk in the common language of molecular and cellular biology with applications to pathophysiology. This, hopefully, will be a historic weekend for the future of these kinds of relationships.

As you have probably noticed, I don't write many editorials for Science. When I took the job of editor-in-chief, writing editorials was the thing that scared me the most, because I generally don't get angry enough to write them. I knew I didn't know everything about everything there was to know, so I have had the pleasure of calling upon a lot of different people to participate in the editorial column. You will have seen, about four weeks ago, that Vice President Gore wrote an editorial for us called "The Metaphor of Distributed Intelligence." 6 This editorial came from a speech he presented at the annual meeting of the American Association for the Advancement of Science back in February. Gore wanted to call readers' attention to the need to displace the metaphor of the American mass production factory grinding out industrial solutions to modern problems, with the metaphor of massive, parallel computer systems. Each of the parallel processors, when challenged to perform a small part of the task, would send its answer to be collated with the rest of the work that was going on. In his own words, Gore says, "It turns out that this distributed intelligence approach is more effective for solving most problems," which I think is very good insight on the part of the Vice President. He goes on to say that failure to adapt this metaphor may be "why scientific concepts sometimes elude the vast majority of our elected officials." He points out the vicious circle we've all experienced, in which "individuals' lack of scientific understanding undercuts support for the pursuit of further understanding, which fosters deeper ignorance, which further erodes support for battling that ignorance," and then we get

\footnotetext{
${ }^{6}$ Published in Science, Volume 272, 12 April 1996.
}

these very stiff-necked people who don't understand why we have to do research at all. The Vice President wants a "learning society" whose government would fund both basic research and applied technology, ultimately to provide progress and prosperity.

I think that what Gore has to say is important to bring to your attention because it is relevant to what must frustrate all of you, as much as it does me when I am at Scripps trying to do research. There is an extreme situation in the competition for funding, at a time in our scientific evolution when we are ready to harvest the knowledge of our distributed intelligence, whether it is in molecular genetics, cell biology, or combinatorial chemistry, neuroscience, epidemiology, or preventive medicine. I don't mind competing, but I am frustrated at having to spend so much time writing a myriad of different proposals to get funds that I am unable to reap what my colleagues and I, and many of you and your colleagues, have invested so much of our lives to be able to harvest. It makes me want to know (though I am not ready to write an editorial on this yet), Is there no better way for us? Are we so unimaginative that we can't think of a better way to provide for our present and our future? Is the only way the country can balance the past budgetary deficits to cut out the small wedges of discretionary funding that sustained our whole research enterprise?

I think it is the federal government's lack of understanding of the nature of fundamental research that fails to distinguish us from other dimly perceived national needs that Congress pours money into. I don't think those in government see the difference between funding academic research to fuel future prosperity and selling off the strategic oil reserves because the price of gas goes up in California. I don't think they see the difference between funding academic research and buying 50 million dollars worth of beef to provide lunches to school children, when, in reality, the latter is to stifle the screaming of cattle farmers who cannot sell their beef and are paying the highest grain prices they ever have because we pay our farmers not to raise grain. The farmers cannot sell the grain to feed the cows, which we don't want to eat anyway because it gives us atherosclerosis and possibly mad cow disease. The President thus agrees to pay 50 million dollars, just like that, to buy up excess livestock. Not to be outdone, the National Pork Producers Association note that pork, lamb, turkey, and chicken producers are also crunched by 
the same grain shortages and ask the government to declare its intentions now, so that before spring is up the farmers can know whether to plant or not. You might also have seen yesterday's headline, in which the salmon producers of Alaska say that we must buy up all of last year's excess frozen salmon because now is the time when the Alaskan fisheries have to go out and catch more fish. If we don't sell off last year's salmon, the price of this year's salmon won't make it profitable for them to catch the fish, and, if they don't catch the fish, the fish won't be able to swim back to the breeding grounds because there will be too many of them. Now, where in any of that is the subsidy for intellectual research? Where in any of that is an awareness of what it is that we have got to do?

It was because of my frustration that I was drawn to the little article that Harvey Sapolsky wrote for Technology Review back in November of last year. He noted that U.S. governmental support of academic research is no longer motivated by Cold War threats, or by the fear of economic domination of countries like Germany and Japan. (Japan, by the way, is clearly manifesting its interest to support basic biomedical research: they put extra billions of dollars into both the research and the training of researchers). Sapolsky concluded that health research now provides the best impetus for continued strong investment in academic research. Health research is a hightechnology field. It provides a range of opportunities from physics to chemistry to biology to surgery to research product development and services on a grand scale. We must, therefore, maintain the flow of basic science in order to foster this one strong industrial skill.

These are the issues that concern me. These are the issues that I think face us as medical scientists who want to solve these problems and who experience this frustration at a time when we see little of our leadership doing much beyond maintaining the status quo, beyond insisting that where we are is the best we can hope for and that we should be very pleased at our 5\% increases. I hope that including Science magazine in the partnership of the research societies and "Biomedicine '96" can be seen as a means by which we at Science can assist in the success of these efforts by alerting new participants, whatever their background, to the opportunities in the wide field of biomedical research. To those of you who are open to examining the opportunities, I think you will find it a challenging future. 